\title{
Rediscovery of Ipomoea salsettensis (Convolvulaceae) from Western Ghats of Maharashtra, India
}

\author{
A.V. Kattee ${ }^{1}$, D.B. Borude ${ }^{2}$, A.N. Chandore ${ }^{2}$, C.R. Patili, ${ }^{1,3}$ and V.B. Shimpale ${ }^{1 *}$ \\ 'Department of Botany, The New College, Kolhapur -416012, Maharashtra, India. \\ 2Department of Botany, Abasaheb Marathe Arts \& New Commerce, Science College, Rajapur, \\ Ratnagiri - 416702, Maharashtra, India. \\ ${ }^{3}$ D.K.A.S.C. College, Ichalkaranji - 416115, Maharashtra, India. \\ *E-mail: shimpale@yahoo.com
}

\begin{abstract}
Ipomoea salsettensis Santapau \& Patel (Convolvulaceae) is rediscovered from the Western Ghats of Maharashtra, after a lapse of 58 years. A detailed taxonomic description, illustration, photographs and relevant notes are provided.
\end{abstract}

Keywords: Ipomoea salsettensis, Maharashtra, Rediscovery, Western Ghats

\section{Introduction}

While conducting revisionary studies on genus Ipomoea L. for India, the authors collected some interesting specimens of the genus Ipomoea. After critical studies, screening of literature (Almeida, 2001; Venkanna \& Das, 2001) and consultation of type (Patel 1509, BLAT!) the specimens have been identified as I. salsettensis Santapau \& Patel. It is an endangered species endemic to Western Ghats of Maharashtra state (Ahmedullah \& Nayar, 1987; Yadav, 1997; Mishra \& Singh, 2001; Singh et al., 2015). The type specimen was originally collected from Borivli National Park, Bombay (now Mumbai) in 1955 and then it was collected from Trombay by one of the original authors (Santapau 23353-4) in 1960 and subsequently by V. P. Patel (1525-28) in 1955 from Bhandup and S.C. Tiwari (T1732) in 1958 from Goregaon after these collections there is no report of its occurrence from any part of the state (Mishra \& Singh, 2001). The present report from the Rajapur tehsil of Ratnagiri district, which is $480 \mathrm{~km}$ away from the type locality, not only forms the rediscovery but also extends its distributional record.

Ipomoea salsettensis Santapau \& Patel, Trans. Bose Res. Inst. Calcutta 22: 34, t. 2. 1958; N.P. Singh \& Sundararagh., J. Econ. Taxon. Bot. 8(1): 32. 1986; Ahmedullah \& M.P. Nayar, Endemic Pl. Indian Reg. 1: 131. 1987; S.R. Yadav in Pokle et al., Fl. Pl. Syst. Divers. 1: 42. 1997; M.R. Almeida, Fl. Maharashtra
IIIB: 333. 2001; Mishra \& N.P. Singh, Endemic Threat. Fl. Pl. Maharashtra: 169. 2001; N.P. Singh et al., Fl. Maharashtra 2: 470. 2001; Singh et al., Endemic Vascular Pl. India 1: 44. 2015.

Figs. 1,2

Type: INDIA, Maharashtra, Bombay, Borivali, 25.9.1955, Patel 1509 (holo, BLAT!).

Twinner, woody, perennial. Stems glabrous, furrowed, minutely warty. Leaves broadly ovate or orbicular, $3-15.5 \times 3.5-15 \mathrm{~cm}$, entire or 3-5lobed, base cordate, apex acuminate or mucronate; petioles 5-8 cm long, verrucose. Flowers 3-6 in umbellate cymes, rarely uniflorate; peduncles c. $17 \mathrm{~cm}$ long; pedicels c. $1.5 \mathrm{~cm}$ long. Sepals unequal, 10-12 mm long, coriaceous, glabrous, deflexed in fruiting; outer lobes obovate or oblong, 10-11 mm long, apex rounded or retuse and mucronate, warted outside; inner sepals broader, smooth, margins membranous, apex rounded and mucronate, mucro emerging from the outer part of sepal, below apex. Corolla salver-shaped, $8-10 \mathrm{~cm}$ long, white; tube slender, 5-5.5 cm long, minutely puberulous inside; limb 4-6 cm in diam., distinctly lobed. Stamens subexserted, subequal; filaments pilose at base. Capsules depressed-globose, 1.5-1.7 cm across, 4-valved, 2-celled; seeds 6-8, tomentose.

Flowering \& fruiting: September-December.

Habitat: It grows on roadsides in bushes. Although it produces profuse flowering, fruit setting is very low. During present investigation about 

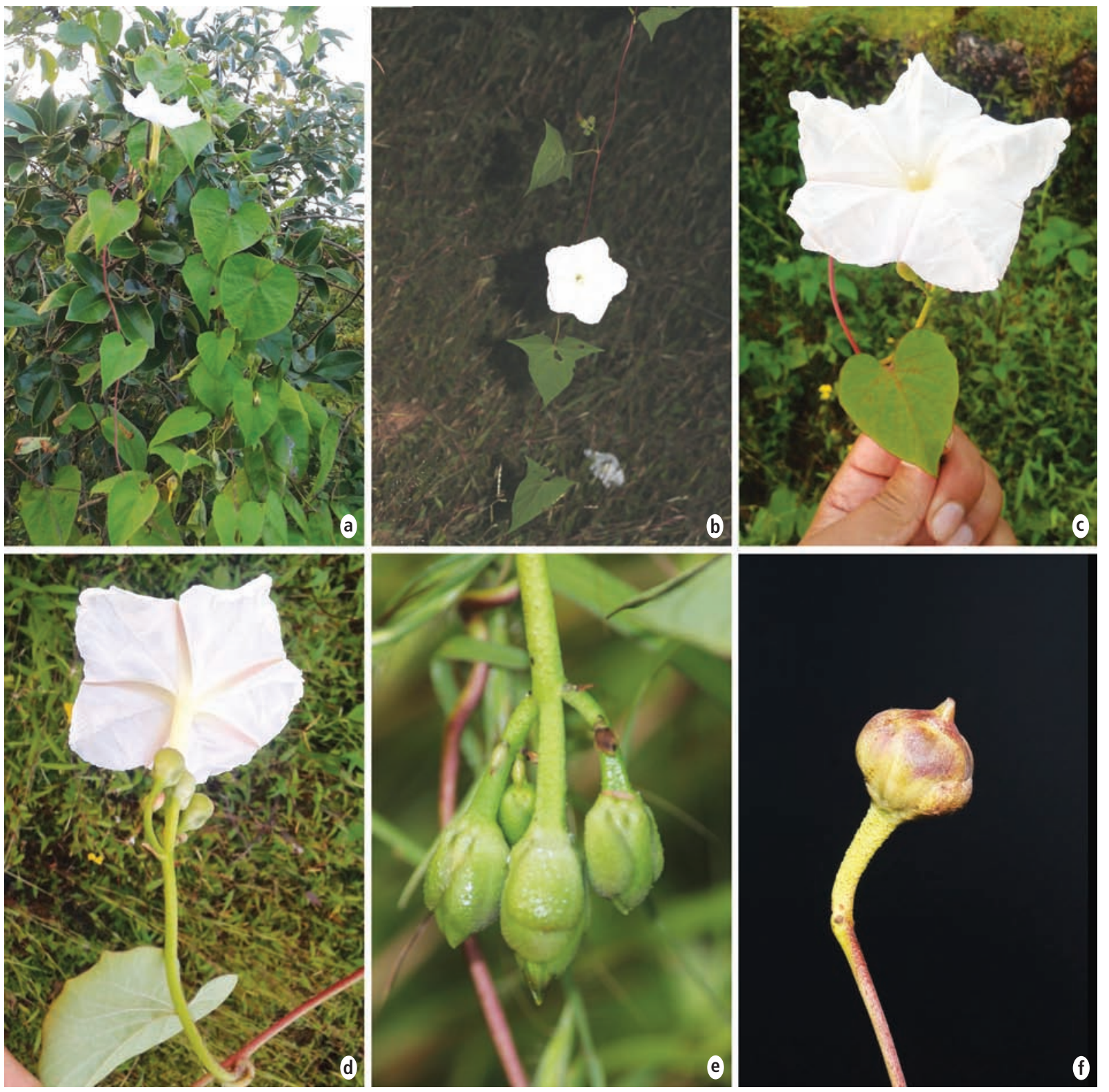

Fig. 1. Ipomoea salsettensis Santapau \& Patel: a. Habit; b. Flowering-twig; c. Flower front view; d. Corolla tube showing midpetaline bands on lower side; e. Flower buds showing sepals; $f$. Fruits

50 individuals were observed in two distinct populations.

Distribution: India: Maharashtra (Mumbai and Ratnagiri districts).

Specimen examined: INDIA, Maharashtra, Ratnagiri district, Rajapur, 14.10.2016, Kattee \& Shimpale 1437 (The New College Herbarium, Kolhapur)

Note: Ipomoea salsettensis is often mistaken for I. alba. Both the species are nocturnal (flowers bloom night), with long white corolla. Key differences between these two species are given in Table 1.

\section{Acknowledgements}

Authors are thankful to the Principal, The New College, Kolhapur and Abasaheb Marathe College, Rajapur, for necessary help and also to Prof. S.R. Yadav, Department of Botany, Shivaji University, Kolhapur, for critical comment on identity. First author (AVK) is thankful to BARTI, Pune, for award of fellowship. 


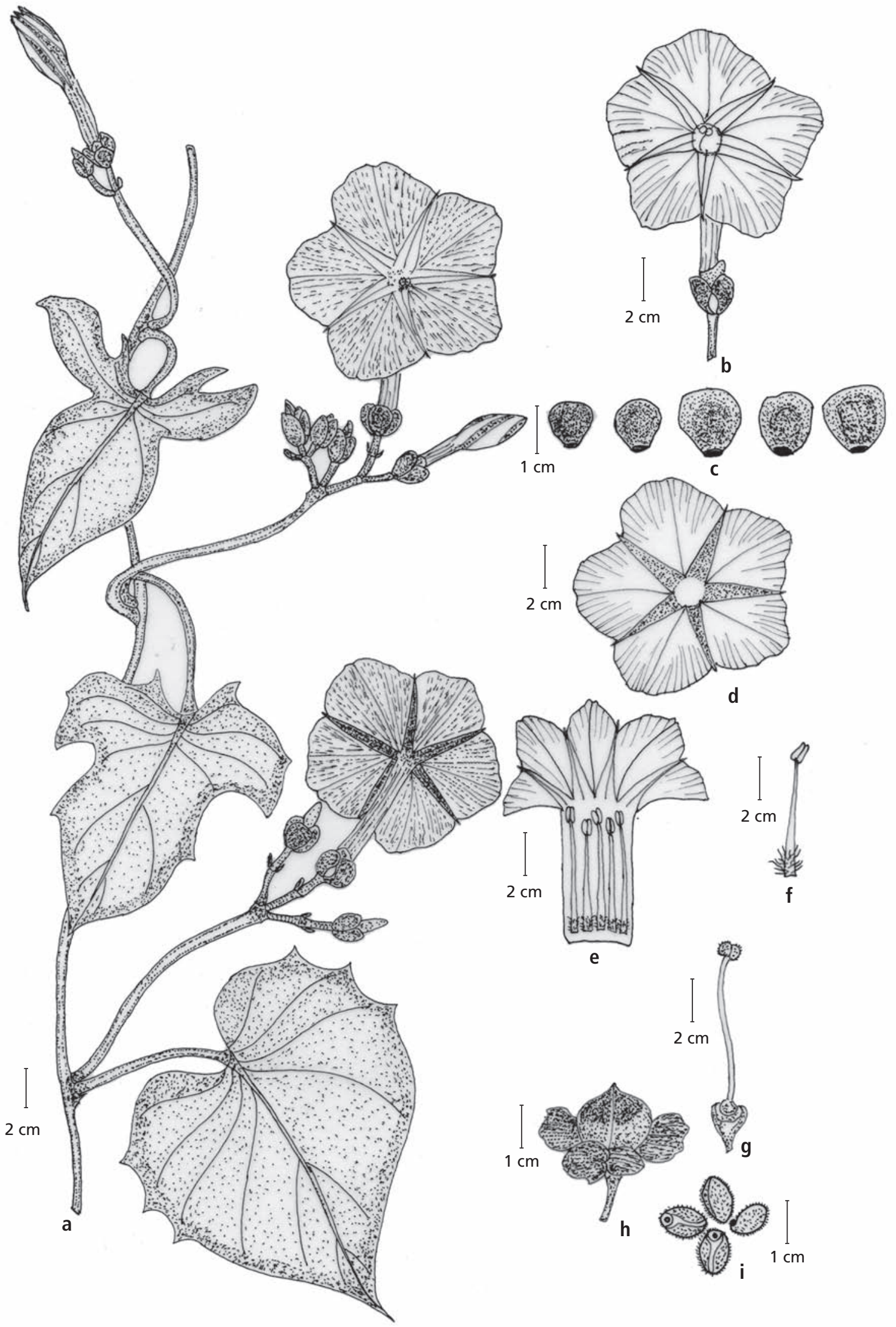

Fig. 2. Ipomoea salsettensis Santapau \& Patel: a. Flowering-twig; b. Flower; c. Sepals; d. Corolla front view; e. Corolla splitopen; f. Stamen; g. Gynoecium; h. Capsule; i. Seeds. 
Table 1. Key differences between Ipomoea salsettensis and I. alba

\begin{tabular}{lll}
\hline Characters & I. salsettensis & I. alba \\
\hline Stem & Furrowed, minutely warty & Smooth, often muricate \\
Sepals & Obovate or oblong, rounded or retuse and & Ovate, strongly mucronate, smooth \\
& mucronate, warty outside and greenish & outside and purplish \\
Corolla & Tube $5-5.5 \mathrm{~cm}$ long; lobes distinct; & Tube $12-15 \mathrm{~cm}$ long; lobes shallow; \\
& mid-petaline bands reddish & mid-petaline bands greenish on \\
& on outer side & outer side \\
Seeds & $6-8$, tomentose, brownish & $2-4$, glabrous, white \\
\hline
\end{tabular}

\section{Literature Cited}

Ahmedullah, M. \& M.P. Nayar 1987. Endemic Plants of the Indian Region. Vol. 1. Peninsular India. Botanical Survey of India, Calcutta.

Almeida, M.R. 2001. Flora of Maharashtra. Vol. 3B. Blatter Herbarium, St. Xavier's College, Mumbai.

Mishra, D.K. \& N.P. Singh 2001. Endemic and threatened flowering plants of Maharashtra. Botanical Survey of India, Calcutta.

Singh, P., Karthigeyan, K., Lakshminarasimhan, P. \& S.S. Dash 2015. Endemic Vascular Plants of India. Botanical Survey of India, Kolkata.
Venkanna, P. \& S.K. Das Das 2001. Convolvulaceae. In: Singh, N.P., Lakshminarasimhan, P., Karthikeyan, S. \& P.V. Prasanna (eds.), Flora of Maharashtra State. Dicotyledons. Vol. 2. Botanical Survey of India, Calcutta. pp. 454-473.

Yadav, S.R. 1997. Endemic plants of peninsular India with special reference to Maharashtra. In: Pokle, D.S., Nanir, S.P. \& V.N. Naik (eds.), Proceedings, VII IAAT Annual Meet and National Conference. Dr. Babasaheb Ambedkar Marathwada University, Aurangabad. pp.31-51.

Received: 29.10 .2016

Revised and Accepted: 22.12.2017 